UDC 547.857:54-128:543.51

DOI: $10.15587 / 2519-4852.2017 .113512$

\title{
DETERMINATION OF THE OPTIMAL PARAMETERS AND IONIZATION PRODUCTS OF RIBOXINUM
}

\author{
M. Rosada, N. Bevz, V. Georgiyants
}

\begin{abstract}
Мас-спектрометрія на сьогоднішній день є одним з найбільш широко застосованим експресним методом аналізу, який використовується для встановлення будови як індивідуальних синтетичних та природних органічних сполук, так і їх сумішей. Одним із способів встановлення будови досліджуваної сполуки цим методом є автоматичне порівняння зареєстрованого спектра з банком спектрів, введених в пам'ять комп'ютера.

Мета. Метою дослідження є визначення оптимальних параметрів іонізації та вивчення фрагментаціі рибоксину при іонізації з подальшим поповненням бібліотеки спектрів приладу.

Методи. Мас-спектрометрія з використанням різних систем для утворення як материнського, так $i$ дочірнього іона з подальшим використанням отриманих даних для підвищення селективності $i$ покращенния чутливості методу.

Результати дослідження. У результаті проведених досліджень вивчена схема фрагментації рибоксину при іонізації на мас-спектрометрі з трійним квадруполем. Встановлені оптимальні параметри іонізачії

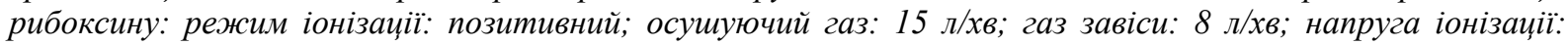
$5000.0 \mathrm{kV}$; температура осушуючого газу: $300.0{ }^{\circ} \mathrm{C}$; потенщіал декластеризації: $40.0 \mathrm{~V}$; потенщіал фокусування: $200.0 \mathrm{~V}$; вхідний потенціал на Q0: $10.0 \mathrm{~V}$; енергія колізї $(Q 2): 20.0 \mathrm{~V}$; потенціал на виході з камери зіткнень (Q2): $25.0 \mathrm{~V}$.
\end{abstract}

Висновки. Отримані результати досліджень є основою для розробки методики кількісного визначення рибоксину у біологічних зразках методом високоефективної рідинної хроматографії $з$ масспектрометричним детектуванням

Ключові слова: похідні пурину, рибоксин, біологічні зразки, іонізаџія, фрагментація, мас-спектрометрія

\section{Introduction}

Physicochemical methods of analysis, namely mass spectrometry, are widely used in the analysis of drugs for identification and quantification. The method is characterized by a high sensitivity, information value, reliability, and is used in combination with gas and high performance liquid chromatography in pharmaceutical and medicinal chemistry, pharmacology, toxicology, environmental protection, forensic expertise and production control.

2. Formulation of the problem in a general way, the relevance of the theme and its connection with important scientific and practical issues

Riboxinum is one of the markers for diagnosing a variety of diseases at early stages, such as coronary heart disease, and early diagnosis of cancer [1,2]. Quantitative fluctuations of markers that indicate the possible presence of a disease are in the concentration ranges at the level of nanograms/milliliter [3, 4].

Determination of low concentrations requires a special approach in quantitation. Sample preparation with the concentration of the sample, and the use of modern analytical equipment are the necessary elements; moreover, it is impossible to perform such a task without them. The modern analytical equipment that allows determining these concentrations accurately requires special approaches during developing the method.

When developing the method for determination of riboxinum in various matrices, including biological ones, with application of the chromato-mass-spectrometric system where the mass spectrometer is used as detector, first of all, it is necessary to determine the optimal parameters of ionization.
3. Analysis of recent research and publications

Determination of riboxinum is carried out using various types of analytical equipment. The approaches for the quantitative determination of riboxinum in biological samples were described by the method of spectrophotometry $[5,6,7]$, mass spectrometry $[8,9]$, as well as the fluorescent method [10].

While developing the method for identification and quantitative determination of riboxinum the mass spectrometers of various types - ESI-TOF/MS and ESI-MS/MS were used. Using the ESI-TOF/MS system it is possible to track formation of the parent ion $\mathrm{m} / \mathrm{z}$. When using the ESI-MS/MS system there is formation of not only the parent ion, but the product ion as well due to the additional fragmentation in Q2. The ability to track product ions increases the selectivity of the system and enables to improve the sensitivity of the method. Therefore, when studying the riboxinum ionization with the use of the ESI-TOF/MS and ESIMS/MS the parent ion $\mathrm{m} / \mathrm{z}$, which was 269 , was determined. When using the ESI-MS/MS system the product ion with $\mathrm{m} / \mathrm{z}$ of 137 was obtained in the process of the additional fragmentation of the parent ion with $\mathrm{m} / \mathrm{z}$ of 269 in Q2 $[11,12]$.

4. Identification of aspects of the problem unsolved previously

This work is devoted to determination of the optimal parameters of the riboxinum ionization using an API 3000 mass spectrometer of "ABI SCIEX" firm since the mass spectrometers of other manufacturers having specific settings each are used in the papers mentioned. 


\section{Formulation of goals (tasks) of article}

The aim of our work is to determine the optimal parameters of the riboxinum ionization, its fragmentation and replenishment of the library of the device with the corresponding spectra of the parent and product ions.

\section{search}

6. Presentation of the main material of the re-

The object of our research was the standard sample of riboxinum batch 5 dated 10.02.2017 (RS SPhU).

The structural formula of riboxinum is presented in Fig. 1, and its molecular weight is $268.23 \mathrm{~g} / \mathrm{mol}$.<smiles></smiles>

Fig. 1. The structural formula of riboxinum

The analytical studies were carried out by mass spectrometry with three quadrupoles on an API 3000 mass spectrometer ("ABI SCIEX", Canada) using AS60/220/C/1 electronic laboratory balances ("RADWAG", Poland), the measuring glassware of class A, a 5 ml HAMILTON syringe for injecting the solution into the mass spectrometer.

The system is a mass spectrometer with the ionization source of the ESI (electrospray ionization) type and three linear quadrupoles. Mass spectrometry is based on determination of the ratio of the mass-tocharge ions $(\mathrm{m} / \mathrm{z})$ formed in ionization of the substance in the sample [13].

Nitrogen obtained from a Parker Balston 75-72 nitrogen generator with the purity of $99.5 \%$ was used as a drying gas. Nitrogen with the purity of $99.999 \%$ was used as a gas supplied to Q2 for the additional fragmenta- tion of the parent ion, and the dry, purified compressed air was a curtain gas.

Since the mass spectrometer is a reliable selective tool in analytical practice, when selecting parameters of ionization we focused on the intensity of the output signal and completeness of ionization.

The optimization was performed using the solution of the standard sample of riboxinum in the concentration of $1 \mathrm{mg} / \mathrm{ml}$. It was injected directly into the detector using a kd Scientific 100 syringe dispenser, the injection rate was 10 $\mu \mathrm{l} / \mathrm{min}$. The optimal parameters for the mass spectrometer ionization during the riboxinum ionization are given below:

- the ionization mode: positive;

- a drying gas: $15 \mathrm{~L} / \mathrm{min}$;

- a curtain gas: $8 \mathrm{~L} / \mathrm{min}$;

- the ionization voltage: $5000.0 \mathrm{kV}$;

- the temperature of a drying gas: $300.0{ }^{\circ} \mathrm{C}$;

- the declustering potential: $40.0 \mathrm{~V}$;

- the focusing potential: $200.0 \mathrm{~V}$;

- the input potential at Q0: $10.0 \mathrm{~V}$.

The spectrum obtained in the riboxinum ionization in Q1 under these conditions is presented in Fig. 2. From the data presented it is seen that under the ionization conditions there is a high signal intensity, a clear peak of the parent ion, which $\mathrm{m} / \mathrm{z}$ corresponds to $\mathrm{m} / \mathrm{z}$ of riboxinum in the positive mode of ionization.

When obtaining product ions the parameters of ionization are as follows:

- the energy of collision (Q2): $20.0 \mathrm{~V}$;

- the output potential from the collision chamber (Q2): $25.0 \mathrm{~V}$.

The spectrum of product ions under these conditions is given in Fig. 3.

From the spectrogram can be seen that under these conditions the completeness of ionization of the parent ions is very high, the peak of the product ion has a high intensity.

According to the results of the experimental studies the scheme of the riboxinum fragmentation in ionization on the mass spectrometer with triple quadrupole is as follows (Fig. 4).

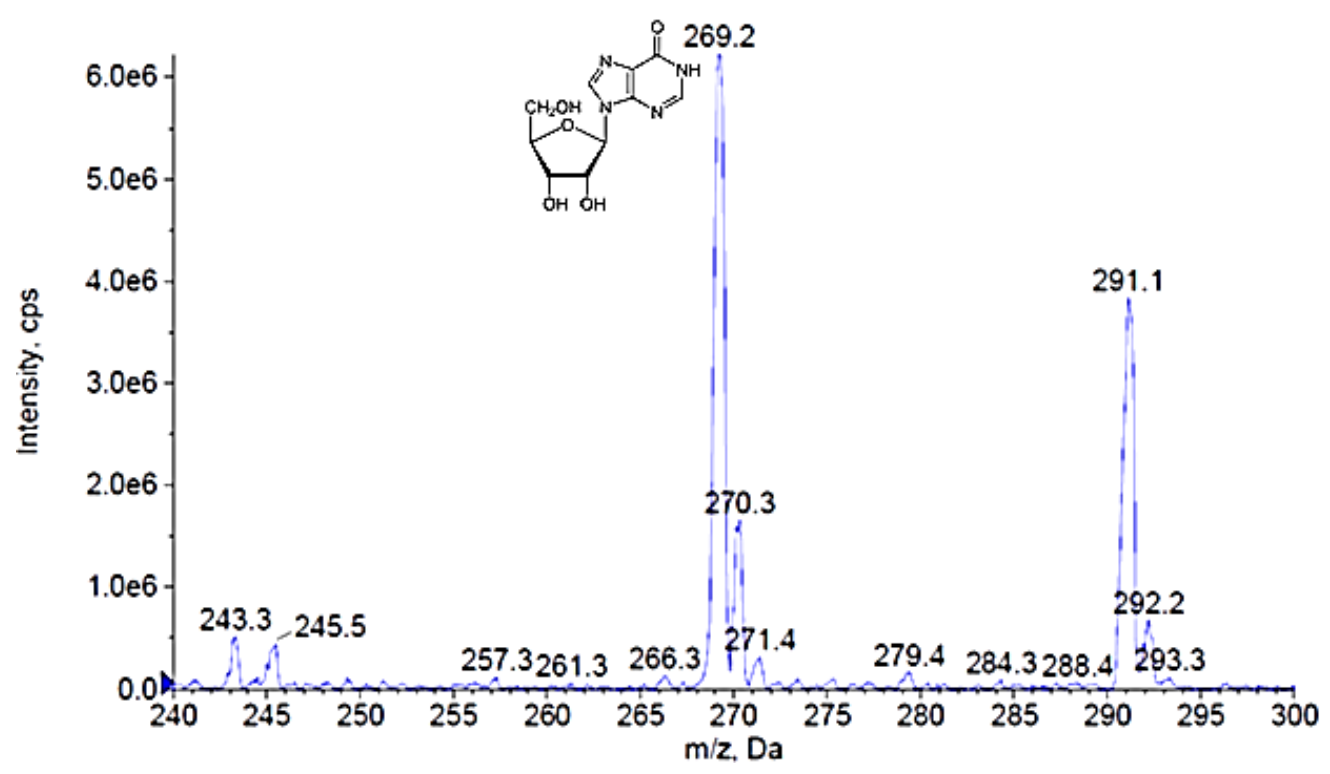

Fig. 2. The spectrum of the riboxinum ionization 


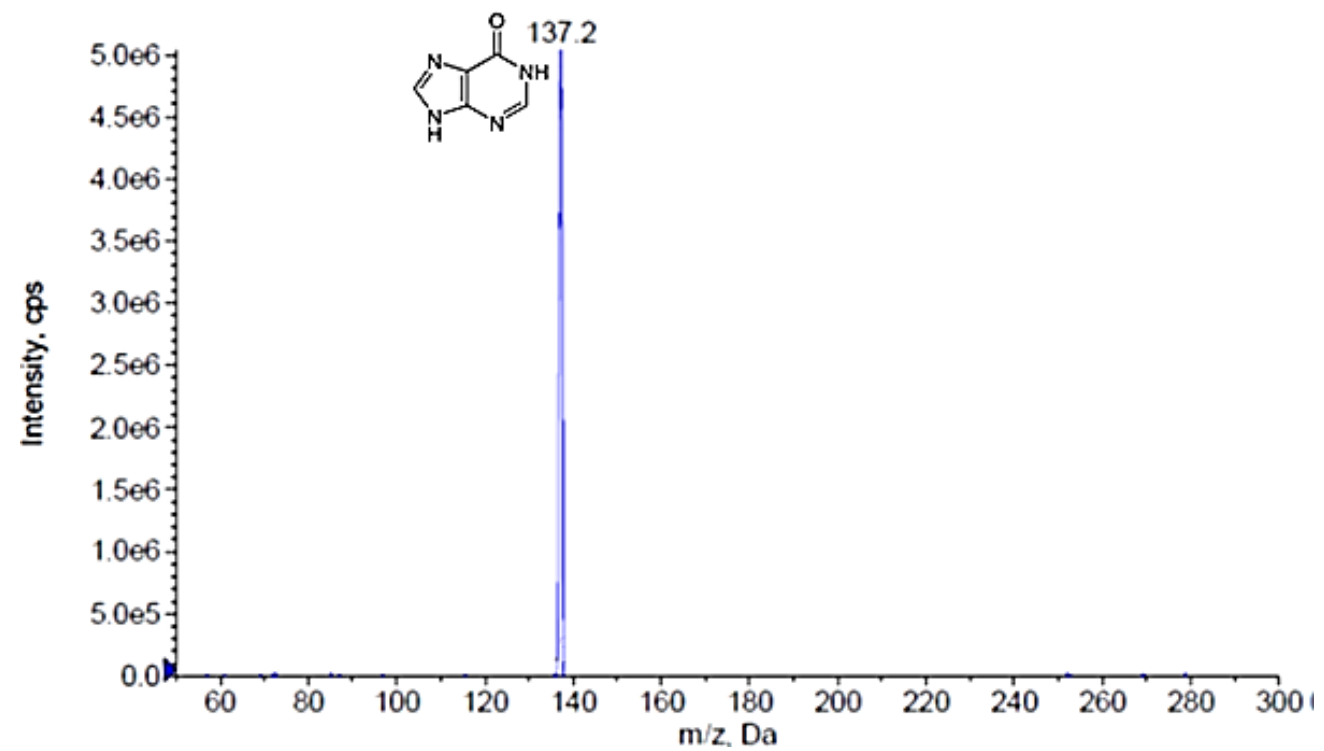

Fig. 3. The spectrum of product ions<smiles></smiles>

$\mathrm{m}=268.2 \mathrm{~g} / \mathrm{mol}$

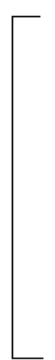<smiles></smiles>

$\mathrm{m} / \mathrm{z} 269.2$<smiles>O=c1[nH]cnc2[nH]cnc12</smiles>

$\mathrm{m} / \mathrm{z} 137.2$

Fig. 4. The scheme of the riboxinum fragmentation in ionization

During ionization of riboxinum, which molecular weight is $268.23 \mathrm{~g} / \mathrm{mol}$, the parent ion with $\mathrm{m} / \mathrm{z} 269.2$ is formed. Fragmentation of parent ions in Q2 leads to formation of product ions with $\mathrm{m} / \mathrm{z}$ 137.2. This corresponds to a fragment with the molecular weight of 136.1 (hypoxanthine) [11].

\section{Conclusions and prospects for further research}

The optimal conditions for the riboxinum ionization, in which the maximum parent and product ions form, have been developed. It allows stating about the high sensitivity of the method under these conditions of ionization.

The results obtained are the basis for developing the method for the quantitative determination of riboxinum in biological samples by high-performance liquid chromatography with mass spectrometry-based detection.

The library of mass spectra of the device for rapid identification of riboxinum in the samples has been replenished.

\section{References}

1. Farthing, D. An HPLC method for determination of inosine and hypoxanthine in human plasma from healthy volunteers and patients presenting with potential acute cardiac ischemia [Text] / D. Farthing, D. Sica, T. Gehr, B. Wilson, I. Fakhry, T. Larus et. al. // Journal of Chromatography B. - 2007. - Vol. 854, Issue 1-2. - P. 158-164. doi: 10.1016/j.jchromb.2007.04.013

2. Platonova, N. A. Farmakodinamika bemitila i riboksina u bol'nykh s khronicheskoy serdechnoy nedostatochnost'yu [Text] / N. A. Platonova // Vestnik VolgGMU. - 2006. - Vol. 1. - P. 50-51.

3. Farthing, D. E. Investigation of inosine and hypoxanthine as biomarkers of cardiac ischemia in plasma of nontraumatic chest pain patients and a rapid analytical system for assessment [Text] / D. E. Farthing. - Virginia: Virginia Commonwealth University Richmond, 2008 - 211 p.

4. Hsu, W.-Y. Analysis of urinary nucleosides as potential tumor markers in human breast cancer by high performance liquid chromatography/electrospray ionization tandem mass spectrometry [Text] / W.-Y. Hsu, W.-D. Lin, Y. Tsai, C.-T. Lin, H.-C. Wang, L.-B. Jeng et. al. // Clinica Chimica Acta. - 2011. - Vol. 412, Issue 19-20. - P. 18611866. doi: 10.1016/j.cca.2011.06.027

5. Kugler, G. A column chromatographic method for determination of plasma and erythrocyte levels of inosine and hypoxanthine [Text] / G. Kugler // Analytical Biochemistry. - 1978. - Vol. 90, Issue 1. - P. 204-210. doi: 10.1016/ 0003-2697(78)90024-6 
6. Chitta, R. Determination of Adenosine and Inosine in Sheep Plasma Using Solid Phase Extraction Followed by Liquid Chromatography with UV Detection [Text] / R. Chitta, M. Pendela, R. Yekkala, P. Herijgers, J. Hoogmartens, E. Adams // Analytical Letters. - 2010. - Vol. 43, Issue 14. - P. 2267-2274. doi: 10.1080/00032711003717323

7. Severini, G. Liquid-Chromatographic Determination of Inosine, Xanthine, and Hypoxanthine in Uremic Patients Receiving Hemodialysis Treatment [Text] / G. Severini, L. M. AIlberti // Clinical Chemistry. - 1987. Vol. 33, Issue 12. - P. 2278-2280.

8. Jimmerson, L. C. A LC-MS/MS Method for Quantifying Adenosine, Guanosine and Inosine Nucleotides in Human Cells [Text] / L. C. Jimmerson, L. R. Bushman, M. L. Ray, P. L. Anderson, J. J. Kiser // Pharmaceutical Research. - 2016. - Vol. 34, Issue 1. - P. 73-83. doi: 10.1007/s11095-016-2040-z

9. Inoue, K. Development and Application of an HILIC-MS/MS Method for the Quantitation of Nucleotides in Infant Formula [Text] / K. Inoue, R. Obara, T. Hino, H. Oka // Journal of Agricultural and Food Chemistry. - 2010. Vol. 58, Issue 18. - P. 9918-9924. doi: 10.1021/jf102023p

10. Jabs, C. M. Adenosine, Inosine, and Hypoxanthine/Xanthine Measured in Tissue and Plasma by a Luminescence Method [Text] / C. M. Jabs, P. Neglen, B. Ekiof, E. J. Thomas // Clinical Chemistry. - 1990. - Vol. 36, Issue 1. - P. 81-87.

11. Zhao, H.-Q. Characterization of Nucleosides and Nucleobases in Natural Cordyceps by HILIC-ESI/TOF/MS and HILIC-ESI/MS [Text] / H.-Q. Zhao, X. Wang, H.-M. Li, B. Yang, H.-J. Yang, L. Huang // Molecules. - 2013. Vol. 18, Issue 8. - P. 9755-9769. doi: 10.3390/molecules18089755

12. Chen, F. Simultaneous Determination of 10 Nucleosides and Nucleobases in Antrodia camphorata Using QTRAP LC-MS/MS [Text] / F. Chen, F. Zhang, N. Yang, X. Liu // Journal of Chromatographic Science. - 2014. Vol. 52, Issue 8. - P. 852-861. doi: 10.1093/chromsci/bmt128

13. Klyuev, N. A. Sovremennye metody mass-spektrometricheskogo analiza organicheskikh soedineniy [Tekst] / N. A. Klyuev, E. S. Brodskiy // Rossiyskiy Khimicheskiy Zhurnal. - 2002. - Vol. XLVI, Issue 4. - P. $57-63$.

Дата надходження рукопису 14.08.2017

Mykola Rosada, Postgraduate student, Department of Pharmaceutical Chemistry, National University of Pharmacy, Pushkinska str., 53, Kharkiv, Ukraine, 61002

E-mail: rosadanv@gmail.com

Nataliia Bevz, PhD, Associate Professor, Department of Pharmaceutical Chemistry, National University of Pharmacy, Pushkinska str., 53, Kharkiv, Ukraine, 61002

E-mail: natali.bevz.60@gmail.com

Victoria Georgiyants, Doctor of Pharmaceutical Sciences, Professor, Head of Department, Department of Pharmaceutical Chemistry, National University of Pharmacy, Pushkinska str., 53, Kharkiv, Ukraine, 61002 E-mail: vgeor@ukr.net 